\title{
Third Gender Rights: The Battle for Equality
}

\author{
Akanksha Mishra*
}

\section{Abstract}

The identity of an individual is often determined by the moral dictates and judgments of the society. However, individuals who seek to challenge these with their personalities, sexual orientations and inclinations are often shunned, abandoned and treated as the "other". Abandoned by families and ridiculed by negative stigmas, they are usually left with no other option, than resorting to begging or singing in weddings, to make a living. Even with such vulnerability to harassment and violence, their agony mostly remains unnoticed. This only indicates the extent of helplessness and neglect this community faces. Various rights granted to this community are seldom potent and welfare measures hibernate on paper. Though the Indian Constitution makes mighty promises prohibiting discrimination of all sorts, there exists ambiguity concerning the concept of gender and the effects that such a prohibition can have on third gender rights. With the Supreme Court taking a proactive step in the NALSA judgment, there has been significant attention drawn towards transgender rights, which will be examined in the paper subsequently. Highlighting the historical growth of the transgender people and analyzing their position in jurisdictions across the world, this research paper aims to shed light on the

*Fourth Year, Symbiosis Law School, Pune, India; akanksha.mishra@symlaw.ac.in 
murky world of suffering and discrimination this community has been relegated to in India. Despite some positive developments that have contributed to increased awareness and recognition of their plight, major problems still plague this section of the society. In addition to the social and legal position of the transgender community and the judicial treatment of the same, the paper also seeks to act as an expose when it comes to make-believe cases of being transgender.

Keywords: Constitution, Equality, Fundamental Rights, Gender Third Gender

\section{Introduction}

Conventional distinction of human gender into male and female is exclusively based on the biological design of their genitalia. However, in reality, there are people who do not fit into this custom and defy the biological binary. These are the 'transgender' people. Stereotyped as the mendicants who knock on the rolled up windows of our cars at traffic signals or as dancers in a local bar, these transgender persons live a life fraught with troubles. The dictionary meaning of the prefix "trans" means "beyond," "across," or "over." However, "transgender" does not simply signify a gender that crosses the borderline. Often, this term is not properly understood by the general population. It is a broad term to circumscribe all individuals who live a major portion of their lives manifesting an innate sense of gender which deviates from suppositions of their birth sex.

In India, some of the regional terms are used to represent the community. For example, the term kothi signifies a range of feminine identified people, who have been assigned male gender at birth. Similarly, other prominent regional and trans-regional identities representing this community are hijras, aravani, jogtas/jogappas, and shiv-shaktis. This rambling constitution of 'transgender' subsumes many 'regional' terms and identities. Hence, the desire for a rigid definition, set the platform for the NALSA judgment which defined the term in the following words, a "transgender is generally described as an umbrella term for persons whose gender identity, gender expression or behaviour 
does not conform to their biological sex."1Thus, it can be said that the term 'transgender' is not only limited to persons whose genitals are intermixed but it is a blanket term used to refer to persons with identities that do not get along with the strict dual categories of man and woman and whose gender identity and expression differs from the conventional norms expected from their birth sex.

\section{History of Transgenders in India}

Indian Mythology offers glimpses of reality at times and a brief look at the reflections of the past, stipulate that the transgender persons who are often denigrated today were once venerated and appreciated to a great extent. The starting point of the concept of third gender can be traced from the Hindu Mythology which has many examples of deities changing gender, manifesting as an Avatar of opposite sex etc. Gods were often considered to be represented as both male and female at different points and in various incarnations. For example, Ardhanarishvara, formed by integrating Lord Shiva and his consort, Parvati, is widely worshipped.

Mahabharata and Ramayana were the treasure boxes for references to transgender people. Shikhandi from Mahabharata is probably the most powerful transgender figure found in the Hindu mythology. Aravan or Iravan, son of Arjuna is another minor, yet crucial transgender character who is believed to have laid down the lineage from which the transgender persons are born. Another episode in the Mahabharata which witnesses the presence of third genders include the time when Arjuna was sent to exile. There, he assumed the identity of Brihandala, a eunuch and performed rituals during occasions of weddings and childbirths. Ramayana is another source inspiration for the emergence of transgender people. Rama, while leaving for the forest for fourteen years, asked his followers, addressing them as "men and women", to return to the city. Among them, the hijras did not feel bound by the order and decided to stay with him. Impressed with the devotion, Rama

${ }^{1}$ National Legal Services Authority v. Union of India \& Ors, (2014) 5 SCC 438. 
conferred powers on them to give blessings on auspicious occasions. ${ }^{2}$ Indeed, during the Mughal Empire (1526-1857), hijras were known for positions held in Royal Courts as political advisors, administrators, generals as well as guardians of the harems. They even occupied high positions in the Islamic religious institutions and were also able to influence state decisions. Later, these benefits were removed through legislation in the British period. ${ }^{3}$

\section{Transgender: No Longer Revered}

Their fall from poise, started in the $18^{\text {th }}$ century during the British colonial rule.4. They lived on the fringes of Indian Society and faced discrimination in workplaces, jobs, public places and services such as health and education. As members of the marginalized and socially excluded sector, they were always at the receiving end of negative behaviour and attitude. This unacceptability by the public, limited their social contributions, resulting in low self confidence and self respect, which consequently isolated them from the society. The abominable state of the transgender persons worsened with the society viewing and treating them as "different" people, not capable of fitting into the prescribed sanctimonious bounds. Ostracized due to their gender identity, they found begging, prostitution as their only source of livelihood. To improve the situation, certain rights were guaranteed to them but the implementation of the same was fraught with insurmountable hurdles, due to the dominating binary gender concept of male or female. For example, in 1994, transgender persons got voting rights but the task of issuing them voter identity cards got caught up in

2 Siddarth Narrain, Being A Eunuch (Oct. 14,2003), http:// www.countercurrents.org/ gen-narrain141003.htm.

${ }^{3}$ M. Michel Raj, Historical Evolution of Transgender Community in India, 4 ASIAN REVIEW OF SOCIAL SCIENCES 18, 17-19 (2015).

${ }^{4}$ Id at 18. 
the male or female question. Several of them were denied cards with sexual category of their choice. ${ }^{5}$

\section{Legality of Marriage}

Corbett $v$. Corbett ${ }^{6}$ was the first case to discuss about marriage involving sex change. In this case, the Court held that notwithstanding the sex change, the respondent was still a male and a marriage between males was void. Further, the principle used in the previous case was applied in the case of $R v$. Tan where, it was held that post operation of change of sex, a male still remains a man by law. In India, it is observed after further consideration that neither the Hindu Marriage Act nor the Special Marriage Act includes transgender people in their umbrella. Eunuchs are not protected under National Commission for Woman since they do not form a part of fairer sex. Section 2(c) of National Commission for minorities which defines minority communities as Muslims, Christians, Sikhs, Buddhists does not cover transgender persons either. Interestingly, in the international legal order, there is silence on the status of the transgender in certain documents. The preamble of UDHR, the seminal document on Human Rights, reads "whereas the people of United Nations have in the charter reaffirmed their faith in fundamental human rights" in the dignity and worth of human person \& in the equal rights of man and woman and have determined to preamble social progress \& better standards of life in larger freedom. The Charter of United Nations also has given no place to this gender. ${ }^{8}$

\section{Legal Visibility to Third Gender Rights}

On April 15 th, 2014, after years of discrimination and hostility, the transgender persons could finally wear the legal costume of a

${ }^{5}$ Manoj K. Jha, Transgender Rights in India,http://iasscore.in/nationaldetails-74.html (Last visited on Jan. 15, 2016).

${ }^{6}$ Corbett v. Corbett, (1970) All ER 33.

7R v. Tan \& Greaves, (1983) 2 All ER 12.

8 INDRANI SEN GUPTA,HUMAN RIGHTS AND SEXUAL MINORITIES: TRANSGENDER HUMAN RIGHTS (Gyan Publishing House, 2005). 
separate identity, after Supreme Court, in the landmark judgment of National Legal Services Authority v. Union of India $\mathcal{E}$ Ors.9, recognized the third gender category in the eyes of law. The Court finally busted the bubble of binary gender structure of 'man' and 'woman' and granted equal rights and protection to transgender persons under the constitutional principles of Article 14, 15 and 16. In Article 14 of the Indian Constitution, which deals with Equality before law, the term 'person' does not restrict itself to the dual concept of man and woman. Thus, Hijras/transgender persons who are neither male nor female, also fall within the expression 'person' and are entitled to legal protection of laws in all spheres of State activity. Furthermore, Articles 15 and 16 are used to broaden the scope of 'sex' to include 'psychological sex' or 'gender identity' and hence held that no one could be discriminated on the grounds of sexual orientation. The Court also made an effort to protect one's gender expression which is majorly reflected through dresses, actions, behaviour and similar forms. The Supreme Court stressed on the importance of right to dignity by recognizing one's gender identity within the ambit of Article 21 of the Indian Constitution.

Further, beyond prohibiting discrimination and nuisance, the Court extended the global principles of dignity, freedom and autonomy to this unfairly marginalized and vulnerable community and met the norms of Universal Declaration of Human Rights and 1948, the International Covenant on Economic, Social and Cultural Rights, 1966, the International Covenant on Civil and Political Rights, 1966 as well as the Yogyakarta principles. ${ }^{10}$ Based on proper pronouncements and philosophical ideologies as well, this landmark decision, for the first time, gave due recognition to gender identity based on the reassigned sex after undergoing Sex Reassignment Surgery(SRS) and explained that the person has a constitutional right to get the recognition as male or female after SRS, which was not only his/her gender characteristic but has become his/her physical form as well. In September 2014, Ministry of Social Justice and Empowerment followed up with an

${ }^{9}$ National Legal Services Authority v. Union of India \& Ors, (2014) 5 SCC 438.

${ }^{10}$ dat 438 . 
"Application of clarification/modification" to the Supreme Court, which sought to explain the implications of the judgment with regard to the recommendations of the aforementioned expert committee report.

\section{The NALSA Judgment: A Ray of Hope}

The NALSA judgment should certainly be lauded for condemning discrimination due to gender and for bringing hope and promise to a community which has always been far outside the ambit of legal framework. With immense faith and vision, the judges have given a legal identity to all those persons whose bodies which do not match up with the accepted gender standards at birth. One revolutionary aspect of the judgment came as a major implication for the current laws related to marriage, adoption, labour laws and inheritance which will now have to move away from the binary system of male and female in order to facilitate the legal rights of transgender persons. Further, it is impossible to ignore the irony that the judgment was delivered only a few months after the case of Suresh Kumar Koushal and another v. NAZ Foundation and Others ${ }^{11}$ which upheld the constitutionality of Section 377 of the Indian Penal Code. The Court, accepting that Section 377 is discriminatory against the transgender persons, clarified that the judgment leaves the Koushal case uninterrupted and thus single-handedly focusing on the legal recognition of the trans-sexual community. One of the most innovative turn in the judgment was the involvement of fundamental rights directly from the Constitution, especially the application of Article 19, thus, acting as a bold motive in acknowledging the rights of a transgender being.

The remedies that the Court awards are also exceptionally fascinating. Three mandates have, as of now, been mentioned: that hijras are currently perceived as the third sex, that trans-persons have the privilege to pick between being male, female or having a place with the third gender, and that transpersons are to be given benefits that are duly offered under governmental policies

11Suresh Kumar Koushal and Anr. v. NAZ Foundation, Civil Appeal No. 10972 of 2013 (Supreme Court, 11/12/2013). 
regarding minorities, since they would qualify as a 'socially disadvantaged, backward class'. The Court goes ahead to give a large number of different bearings, including some particular orders (like providing user friendly toilets and treatment for HIV affected trans-persons); some expansive ones (like direction to furnish them with medical care in all doctor's facilities, to outline different social welfare plans for their advancement, and to find a way to create public awareness to guarantee their social consideration); and some uncertain ones (like the direction to truly address issues being faced by them and to take measures to guarantee a respectful place for them in social and cultural life).

\section{Critical Analysis: Gaps in the Judgment}

A considerable measure of confusion has really emerged from the judgment. Indeed, even as the omnipresent media and civil society was commending the judgment, numerous transgender people were pointing out its innate issues and inconsistencies. An extensive list of reactions by observers and collectives has been posted by Orinam. ${ }^{12}$ In one of them, Gee Imaan Semmalar offers an in depth critical analysis of the content of the judgment ${ }^{13}$, and its conceivable implications. He states that the judgment, which he finds "confusing and confounding," conflates various transgender personalities, for instance referring to all hijras as 'third gender', when in reality there exists differences between the two.

The author also observes that the judgment oscillates between broad and narrow interpretations of the term 'transgender' and between self-determination of identity and its biological requirements. Justice Radhakrishnan's wide definition of

12 Supreme Court ruling on Transgender rights, http:/ / orinam.net/resources-for/law-and-enforcement/nalsa-petition-tgrights-india/, (Last visited on Feb. 24, 2016).

${ }^{13}$ Gee Imaan Semmalar, Gender Outlawed: The Supreme Court judgment on third gender and its implications, April 19, 2014, http:/ / roundtableindia.co.in/index.php?option=com_content\&view=arti cle\&id=7377:because-we-have-a-voice-too-the-supreme-court-judgmenton-third-gender-and-its-implications\&catid=120:gender\&Itemid=133. 
'transgender' was further narrowed down by Justice Sikri's section of the definition which explicitly leaves out Lesbian, Gay and Bisexual (LGB) people from the ambit of 'transgender'. Justice Sikri's definition clearly acts out in contradiction to specific parts in the judgment, which states that LGB people also come under the umbrella of gender variant people. Moving further to the nine important directives given by the Court in the judgment, at some points, these orders seemed to confuse 'transgender' with 'hijra' by repeatedly using the phrase transgender/hijra, specially in the fourth and the fifth directive. This led to the judgment being perceived as pertaining to just the recognition of 'hijras' as 'third gender', thus, eliminating the recognition of the umbrella term, which includes other gender variants too.

One of the biggest flaws in the judgment, according to the author, is that the entire principle, upon which the judgment of Koushal $v$. $\mathrm{Naz}^{14}$ was raised, collapsed along with the NALSA case. When we focus on sexual orientation, one's identity has no meaning if he can't express it. A statute/law that targets on the conduct, which is the very expression of identity, thereby targets the identity itself. Therefore, when Sec. 377 prohibits homosexuals from engaging in same-sex intercourse, it doesn't just illegalize a set of acts - in prohibiting the most basic expression of one's sexuality, it criminalizes sexuality - and thereby, identity itself. Further, the judgment is unclear and even contradictory about the requirement of medical transition procedures for self-identification of gender. At first, Justice Radhakrishnan based the judgment on Argentinean model of gender recognition which does not involve any kind of medical procedure and yet, at other times, he suggested 'psychological tests' for self identity of transsexual persons. Such conflicting propensities imply that the elucidation and execution of the judgment can be varied and irregular restricting its affirmative action.

\section{Post Judgment Scenario: The Two Sided Coin}

The judgment was definitely a constructive step towards humanization of the judicial system and was a major step towards 
eliminating the injustice done to almost five million people who were running from one place to another without any identity. The Supreme Court's ruling acted as the conformity to basic human rights and people's dignity, finally assigning the true meaning to Right to life and human dignity guaranteed under Article 21 of the Constitution of India.

The first stream of development was seen with the constitution of an Expert Committee to make an in-depth study of all the difficulties faced by the transgender community and further suggest measures to mitigate their problems and finally submit the report along with the suggestions and recommendations within three months of its establishment.15. The cloak of invisibility of transgender persons was first seen to wear out successfully in Tamil Nadu, with inclusion of special 'third gender' category for them on ration cards. Further, government orders were issued announcing unfettered access to education and counseling services. More recently, the state's social welfare department announced the constitution of a separate welfare board for transgender people. ${ }^{16}$ Taking inspiration from Tamil Nadu, Maharashtra became the second state to set up a welfare board for transgender persons and also took an initiative to set up the cultural institute dedicated to their community.

\section{The Twin Bills}

Late in April 2015, MP, Tiruchi Siva introduced a private member's bill - the Rights of Transgender Persons bill - in the Rajya Sabha. ${ }^{17}$ In late 2015, MSJE published a draft bill18 which definitely includes very confusing and problematic changes. Even though the bill gives $\mathrm{OBC}$ status to the transgender people, there is a huge

${ }^{15}$ National Legal Services Authority v. Union of India \& Ors, (2014) 5 SCC 438.

16 Tamil Nadu Pioneers in Transgender Inclusion, http:/ /infochangeindia.org/agenda/social-exclusion/tamil-nadupioneers-transgender-inclusion.html, (Last visited on Jan. 12, 2016).

17The Rights of Transgender Persons Bill, 2014, (pending).

18Transgender Bill, http://socialjustice.nic.in/ Home/ Error? aspxerrorpath=/pdf/TGBillFinal.pdf, (Last visited on Feb. 24, 2016). 
question mark surrounding affirmative action. In addition to this, the bill does not explicitly specify how reservations would be allocated as trans-people can come into the category of dalit too, hence, it was not clear whether they would get two sets of reservations or not. Another controversial aspect in the bill, according to the author, is that there is no reservation for education even though there is one for employment. Now, the question that arises is how anyone will access employment without going through the process of proper education.

Hence, it is felt that the change in the intention of law has not been adequately achieved and the law is not given enough sensitization among the executors. Even if the NALSA judgment acknowledges transgender people, the society is still trans-phobic and patriarchal. It is the government's task to properly sensitize people, otherwise it is very tough for such individuals to avail things. Encouragement is required at every level.

\section{Position in Other Countries}

The Author would like to enumerate the position of transgender rights in various countries like Nepal, Pakistan, Bangladesh, etc. Nepal was the first country to establish a third gender category ("other") on citizenship documents, following the Supreme Court's ruling in the country's landmark decision in the case of Sunil Babu Pant and Others v. Government of Nepal, ${ }^{19}$ which ordered the government to scrap all the discriminatory laws and recognized the fundamental rights of transgender persons.

The Supreme Court of Pakistan recognized the rights of eunuchs in the case of Dr. Mohammad Aslam Khaki \& Anr. v. Senior Superintendent of Police (Operation) Rawalpindi $\mathcal{E}$ Ors. ${ }^{20}$ The recognition came as an after effect of the attack and rape of eight hijra wedding dancers, by the local police. This disturbing event led

\footnotetext{
19Sunil Babu Pant and Others v. Government of Nepal, Writ No. 917 of the year 2064 BS (2007 AD), (Supreme Court of Nepal, 21/12/2007).

20 Dr. Mohammad Aslam Khaki v. Senior Superintendent Police, Constitution Petition No.43 of 2009 (Pakistan Supreme Court, 22/03/2011).
} 
Mohammad Aslam Khaki, a lawyer specializing in Islamic law, to file a private case in the country's Supreme Court, asking to recognize hijras as a third gender. This judgment recognized the rights of eunuchs as citizens of the country, subject to constitution of the Islamic Republic of Pakistan, 1993 and further acted as a catalyst to various initiatives taken to protect their legal rights.

The situation in Bangladesh is as follows. Trans-sexual people were given the right to vote since 2009, but true meaning to its implementation was given in November 2013, with the government recognition of 'hijra' as third gender category in all national documents and passports. Further west, Germany was the first European country to officially recognize a "third gender" category on birth certificates. A new law on $5^{\text {th }}$ November, 2013 allowed parents to register the sex of the children as 'not specified' in the case of children with intersex variation. Taking inspiration from Germany, France became the second country in Europe to recognise the identity of third gender by moving away from the rigid biological determinism of man and woman. The case was brought by a 64-year-old plaintiff, who was assigned male at birth, despite genitalia that presented as neither completely male nor female.

\section{Conclusion}

It is distinctly clear from the above observations that transgender individuals with different sexual orientation face intolerance, discrimination and exclusion in the society. This isolation varies from private reasons to the most common social incomprehension.

While judiciary has taken a significant step to remove the stigma attached to the third gender, it is our turn to recognize the true implication of this judgment and prioritize its enforcement. While throwing money at hijras to spurn them away, we are not just insulting these individuals, but are relegating the very basic principle of humanity; even curs are better treated by the love of humanity. Such actions will only lead the transgender community to toil and struggle in the same quagmire of indignity that they have been facing for generations together. In this country where there is a galaxy of reasons to grand reservations, the community 
which is synonymous to social backwardness is seldom thought about. It is hence necessary to not only pen down laws, but also bring them to action for the upbringing of the transgender community to the basic rostrum of human dignity. 